\title{
Homosexuality and the Pediatrician
}

\section{Early Recognition and Preventive Counselling}

\author{
MARSHALL SHEARER, M.D.*
}

\begin{abstract}
Homosexuality is a psychiatric syndrome which begins in childhood. By recognizing some of the predisposing factors early, and then using his influence and knowledge to work towards their correction, the pediatrician can often play a major role in preventing its development.

Homosexuality must be looked upon as the illness which it is. It is not just a "different way of life."
\end{abstract}

\section{T}

HE diagnosis of "homosexual personality disorder" is applied to those adults who derive their primary sexual pleasure from contacts with persons of their own rather than of the opposite sex. Approximately one of every 20 adult males is estimated to be a practicing homosexual. ${ }^{3}$ Despite the fact that homosexuality as usually practiced is a "crime without a victim," those who engage in it have to cope with negative legal sanctions. This adds to their concerns and interferes frequently with psychotherapy. Hence, several august medical and legal bodies, both here and abroad, favor the removal of legal sanction from homosexuality-except for solicitation.2,5 As pressure for legal reform in. creases we must not forget that homosexuality is a disease and as such is a public health problem. Regretfully the entertainment world often portrays homosexuality as a "different way of life," without mention of the many handicaps these people suffer.

Instructor, Department of Psychiatry, University of Michigan Medical School. Ann Arbor, Michigan.
Adult homosexuals are for the most part anxious, preoccupied with finding a partner, fearful of exposure, and unable to form close or lasting relationships with either sex. These concerns hamper creativity and produce a confused and fragmented sense of self. The overt homosexual is usually aware, often acutely, of these difficulties. The "latent" or "covert" homosexual, while not acting out his homosexual desires and sometimes not wholly conscious of them, suffers many of the same psychologic difficulties and problems in interpersonal relationships. Intellectually, most homosexuals would prefer to become heterosexual, but emotionally their greatest gratification is with their own sex.

Until it is established as the preferred mode of sexual gratification, homosexuality cannot properly be diagnosed. Hence, it is a diag. nosis which cannot properly be applied to children.

While there may be much sexual curiosity and activity prior to puberty, young children are essentially "bi-sexual." They can find pleasure in many varieties of sexual stimulation, including perverted sexual behavior initiated by an older person. This capability of obtaining sexual enjoyment in such a magnitude of forms by a child is referred to as polymorphous perverse.

\section{Chind's Sumual Developmen}

Until the age of three or four, the young child is not aware of sexual differences. He discovers sex at about the time he discovers life in the sense of birth and death. Explorations in the sexual area follow. Anatomic comparisons are made with playmates and 


\section{HOMOSEXUALITY}

siblings of both sexes. The mental forms of exploration, thinking and imagining, are utilized to the fullest in making "sense" out of his discoveries. "Would it be better to be a boy or a girl?" "How are they different?" "How are they treated differently?" "Would I have greater advantages if I were like the opposite sex?" The advantages and disadvantages will be chiefly weighed on the scales of parental atritudes and interactions. The young child thus develops and synthesizes a core of preferred sexual identity, most of it consciously. After age six or seven, however, most of it becomes unconscious.

Until age five or six the child's physical maturation does not lag behind his intellectual and emotional development. He has busied himself at emulating grownups. His headlong rush toward adult autonomy, and power and sexuality then becomes temporarily halted with his new realization that physical immaturity will not enable him to partake of such ventures for some years to come. His sexual interests diminish (if allowed by his environment) until the advent of puberty. He adopts his parents' attitudes toward sex and sexual matters, many of which are quite subtly expressed-as for example whether sex is something dirty and unmentionable or a respected fact of life. He adopts the degree of modesty practiced by the family members in the home. The view of sex as being dangerous may come from subtle expressions of a sexual attitude by too frequent admonishments-for example, "Don't take candy from strange men."

During this period of "latency" of sex interests and emulating "grown-up" activities, the child plays for the fun of playing. His sources of enjoyment shift from his own body to others. As his interests move gradually away from himself, it is understandable that the "others" of his new interest are those mose like himself. He prefers boys and she prefers girls. Clubs are formed excluding the "other sex." The baseball and army that replaced the solitary play of the sandbox lead to interest in the other person as a person and to "just messing around" with him-the enjoyment of just being together. This is referred to as the "normal homosexual" period.
Puberty changes capabilities and interests. These include changes of body image, of body functions, and body urges. The development of secondary sexual characteristics are signs to the outside world that cannot be denied. The heightened sexual urge arrives at the height of the normal, close, confidential "homosexual" relationship. One therefore finds early adolescents involved in various forms of normal, mutual "homosexual" exploration, including comparing of sexual knowledge, sex talk, and some sex acts. Overt homosexual explorative acts (including mutual masturbation) may also occur and be essentially normal. These acts are no more indicative that such a child will become a homosexual than the sexual exploration at age four means that he (or she) will become sexually promiscuous as an adult. However, the reactions of adults to these acts can have catastrophic results, engendering a sense of guilt which may lead to lasting personality disturbances.

It is in recognition of these facts that our society wisely encourages contact with the opposite sex at puberty while at the same time placing its greatest taboo on heterosexual intercourse. The strange and unknown always produces fear, and to the boy from the "No Girls Allowed" clubhouse, girls are unknown and scary. Both sexes need help in overcoming their fright and some pushing to learn how to relate with comfort in social situations with their peers. "How are you supposed to talk to one of them, anyhow?" "i:

\section{Genesis of Homosexual Orientation}

Abnormal parental attitudes and behavior are the major cause of deviation from this normal line of development into a permanent adult homosexual orientation. The father who is harsh, punitive and ungiving towards his sons but "putty in the hands" of his daughters is compelling his sons to conclude, "It would be better if I were a gir!" A son's heterosexual development can become compromised critically if in addition either parent encourages a feminine identification (feminine behavior, preferences, fears and attitudes). A father who sees little of his son and is indifferent to him when he does, 


\section{SHEARER}

fails to provide a masculine model which the boy may emulate and thus fails to engender any desire in the boy to "grow up to be a man." This situation is psychologically similar to that of a boy raised without a father due to separation, divorce, or death. Unless another adult man supplies the boy with the psychologic impetus and observational details of being a man, he will adopt the only set of attitudes and behavior he knows-those of his mother and her female friends. The unknown, in this case masculine orientation, also creates fears.

Many distant fathers are "emotionally absent" because of poor relationships with their domineering wives. The son of such a couple is not only deprived of meaningful contact with his father, but sees him as unable to stand up to his mother and frequently is belittled for not being home-"out drinking with the boys and not caring about the family." The son thus perceives his father (and hence men in general) as both subordinate and bad.

Such mothers, as well as those without husbands, all too frequently turn to their sons for the psychologic closeness they need and should receive from their spouses. The situation becomes even more abnormal for the male child if the estrangement between the parents is due to his mother's own psychologic need to have a male dependent on her. The close, binding attachment which inevitably results has all the hallmarks and effects of extreme overprotection. Such a mother will characteristically use her son as a confidant, while at the same time pre-empting his decision-making in order to keep him close and dependent. She interferes with his assertiveness and interrupts his peer relationships.

The harshly punitive acts of a father can also result in a boy fearing masculinity as much as he fears the father himself.

\section{Early Signs and Symptoms}

Both boys and girls with homosexual tend. encies exhibit a pseudo-maturity out of keeping with their chronologic age. They are jealous of and compete with their siblings for parental affection.
Boys in this situation perceive themselves as frail and clumsy. They have excessive fears of physical injury and illness and feel inadequate in most ways. They are reluctant to participate in competitive games, prefer to play with girls rather than with other boys, and are fearful of "roughneck" boys. Their general appearance and demeanor is often effeminate; it is not unusual to find them enjoying housework, sewing, or knitting. There may be occasional bed-sharing between mother and son.

Girls in a parallel situation are generally competitive and aggressive, often preferring boys' activities to the exclusion of feminine interests. Their appearance is often masculine. They have strong hostile feelings to their mothers. There is usually an intimate closeness with their fathers.

The sexually-tinged overstimulation which results from excessive closeness with the parent of the opposite sex accounts for the greater degree of adolescent sexual exploration that homosexuals engage in. ${ }^{3}$ It is Rado's view that the homosexual orientation is a childhood carry-over of a defensive attitude thrown up against even closer and more intimate involvement with the parent of the opposite sex. ${ }^{4}$ In boys this fear of more frankly sexual contact with mother, the fear of being masculine, and the effeminateness may take the form of chronic dressing in women's clothes, called transuestism.

For girls, the degree of "cross dressing" tolerated by our society is much greater. Tomboys are readily accepted. However, when the casual observer has difficulty ascertaining the sex of a girl on second glance because she appears too masculine, that finding is usually indicative of some degree of latent homosexual orientation, and particularly when the girl is an adolescent.

Other indications of a latent homosexual orientation are repeated approaches by older children or adults seeking overt homosewal participation. Apparently such children "send messages" unconsciously that these overtures are not distasteful.

The adult homosexual's difficulty in establishing close relationships can also be traced to the early years. Parental interruption of 


\section{HOMOSEXUALITY}

peer relationships throughour latency and early adolescence never gives the child the opportunity to form a close, confidential relationship with one of his own age. The homosexual's closest tie has been the uneasy, ambivalent one with the parent of the opposite sex, with the child experiencing psychologic demands from the parent which he (or she) could not meet. This gives rise to a fear of establishing close relationships with anyone of either sex over any extended period of time, and leads to the homosexual's need to engage in his homosexual activity with many different people at different times. Most homosexuals spend large amounts of time in endlessly seeking contacts with new partners. A few homosexuals are able to establish an intimate relationship with other homosexuals; however, it is very rare for such an arrangement to last longer than 12 to 18 months (Bieber). Character traits sought in a partner are determined from the very fragmented and ambivalent attitudes toward competitiveness, dependency, adequacy, and love-the feelings which give rise to the homosexuality. This frequent "falling in love" and subsequent disillusionment keeps the homosexual on an "emotional yo-yo." Of all males who acquire venereal disease, about 30 per cent do so by homosexual contact.

\section{Recognition and Management}

During childhood the most reliable sign indicative of future adult homosexual orientation is an excessive fear of illness and bodily injury. Frequent unwarranted visits to the pediatrician's office should arouse his diagnostic suspicion. A good way to probe is to ask casual questions about the boy's participation in sports. This can lead naturally into questions about friends and how the child spends his time, as well as to the extent of the child's involvement with his father in playing games, ecc. Any response by the mother which depreciates or degrades the father is ominous. A good warm relationship with his father, even when father has a minimal amount of time to spend with his son, is basic to sound future heterosexual adjustment.
Dress or mannerisms more appropriate to those of the opposite sex, or excessive clinging to the parent of the opposite sex (especially between father and daughter) should also alert the physician to the possibility of homosexuality. In a boy, undue dependence may first appear as reluctance to leave mother in order to start in school.

Once the emotional difficulty is recognized, the physician should interview the parents and child together to ascertain the scope and depth of the problem, and to enjoin them in constructive efforts. When the family is seen together the attitudes and interactions mentioned earlier become more readily apparent. For example, who does the child ignore, who does he cling to? Does one parent ignore the child? Do the child and one parent freely interrupt the other parent? Are things the latter says ignored or disregarded by the other two? What is the emotional and behavioral reactions of each at such instances? All these observations may be therapeutically commented on, i.e., "You just interrupted him/her and he sighed and folded his arms across his chest. How do you think he/she feels? . . Do you want that response?" or "You just allowed your spouse/child to interrupt. Wasn't what you were saying important? How do you feel about it? . . How does he/she feel about such instances?" (For expansion of this topic see Ackerman. ${ }^{1}$ )

The recommendations called for should then be much clearer. For example, much can be done at times by simply interesting some adult male outside the family in the needs of a fatherless boy. Organizations such as the YMCA, Little League, or even church activities which throw him in contact with men are a few resources which are widely available. Encouraging a divorced or widowed mother to date other men may also be indicated.

A follow up visit to check on the compliance with the "prescription" is essential. Frequently it is only this pressure, knowing that there will be a return visit, that will enable a mother "to get out of the rut."

Counselling with one or preferably both parents over several sessions is usually advisable. (The pediatrician should have no hesitancy to charge for such counselling at his 
full hourly rate.) The pediatrician may feel the need for a psychiatric consultation, though when diagnosed early few cases should require full psychiatric referral and treatment.

\section{Final Comments}

As with other public health problems, prevention is easier, more effective, and more economical than treatment. In general, the factors which mediate against homosexual adaptations are the principles of good mental health. Many of the pathologic relationships seen in families of homosexuals appear also in families with other psychiatric diseases.

The movement to enact legal reforms and remove homosexuality from the list of criminal offenses, other than the act of solicitation, is in keeping with the concept of homo-

\section{BOOK REVIEWS}

An Atlas of Fine Structure: The Cell, Its Organelles and Inclusions

Don W. Fawcetr, M.D., Harvard Medical School. Philadelphia, W. B. Saunders Co., 1966. 448 pp. $\$ 11.00$.

"The principal advances in histology and histopathology in the next few decades will be made with the electron microscope. If the student today is to be able to read the literature of tomorrow with critical understanding, he must be given experience in the interpretation of electron micro graphs."

Here is a collection of 238 magnificent photographs, with explanatory notes, depicting the appearances under the electron microscope of the imner constituents of cells.

\section{Children in the Hospital}

Thest Bergmann in collaboration with AnNA Freud. New York, International Universities Press, Inc., 1965. $\$ 3.00$.

The authors, possessing keen insight into the intricacies of a child's innermost psychic struc- sexuality as a disease rather than a crime The legal and medical aspects must be kept separate, especially in the mind of the physician.

\section{References}

1. Ackerman, Nathan: Psychodynamics of Family Life. New York, Basic Books, 1958.

2. American Law Institute; Model Penal Code (Tentative Draft No. 4), 1955, as quoted in Paulsen, M. G. and Kadish, S. H.: Criminal Law and Its Processes. Boston, Little, Brown \& Co., 1962, pp. 2-5.

3. Bieber, Irving et al.: Homosexuality: a Psycho analytic Study. New York, Basic Books, 1962.

4. Rado, Sandor: An adaptive view of sexual behavior in Psychosexual Development in Health and Disease. Edited by Paul Hock and Joseph Zubin. New York, Grune and Stratton, 1949.

5. Report of the Committee on Homosexual Offenses and Prostitution (Wolfenden Report), Home Office, Scottish Home Department, as quoted in Paulsen, M. G. and Kadish, S. H.: Criminal Law and Its Processes. Boston, Little, Brown \& Co., 1962, pp. 5-8. ture, describe what surgery, bed rest, immobilization, nursing care and separacion from home means to various children in Rainbow Hospital in Cleveland. How little we often know of the effects of what we do to a child as we prescribe and carry out medical treatment. More important, as the authors emphasize, there are many means of offering support to our young patients if we only had the time and ability to listen to them a bit more. This is a beautifully written book which should be read repeatedly by every nurse and physician responsible for hospital care of children.Morris A. Wessel, M.D.

\section{The Prenatal Lumg}

S. ENGEL, Department of Anatomy, Royal College of Surgeons of England. Long Island N. Y., Pergamon Press, 1966. 71 pP. $\$ 7.00$.

A collection of 113 lucid diagrams, photographs, and photomicrographs which illustrate the embryogenesis of the lung as a whole and of its histo. logic consituents from six and one-half weeks through 29 weeks of gestation. The reading text is comparatively scanty. "The conclusion may be drawn that the lung matures towards the seventh 